\title{
DPP9 wt Allele
}

National Cancer Institute

\section{Source}

National Cancer Institute. DPP9 wt Allele. NCI Thesaurus. Code C124981.

Human DPP9 wild-type allele is located in the vicinity of $19 \mathrm{p} 13.3$ and is approximately 50 $\mathrm{kb}$ in length. This allele, which encodes dipeptidyl peptidase 9 protein, plays a role in posttranslational protein cleavage. 